\title{
Advokasi Pelayanan Kesehatan Bagi Buruh Perempuan
}

\author{
Nurkhayati \\ UIN Syarif Hidayatullah Jakarta, Indonesia \\ E-mail: yatinurbus@uinjkt.ac.id
}

\begin{abstract}
Employment development as integral part of national development based on Pancasila and the 1945 Constitution, is held in order development human completely and development the entire Indonesian community for improve dignity, respect and self-esteem of workers and manifest the society whose prosperous, fair, affluent physically and spiritually. Given the importance of the role of laborers in development, especially in the production process, it is naturally that protection, maintenance and development for the welfare of laborers, especially women laborers, should be carried out. Because the laborer position is very weak in compare with the bussinesmen. The position of weak laborer requires the bussiness men to give away social protection guarantee to their laborers. Social guarantee is the right of entire citizen including permanent foreigners. Violations of the implementation of social guarantee means violations of human rights (HAM). This is in line with the mandate of the 1945 Constitution that has been amended namely article 28 letters $d$ ( 1 and 2), letter $h$ (3), and article 34 (2); state that the country protects every citizens and entitled on protection from all kinds of danger, intimidation and equal treatment in carrying out their life. In fact, not all companies giving socal guarantee for their laborers, especially women laborers. In which many women laborers are still catagorized as single even though they are the backbone of the family,-because of having unemployed husband or as single parent. Thus, real action in form of advocacy is needed to change the company's policies. Advocacy is a powerful way to bring positive changes and empower people in their lives.
\end{abstract}

Keywords: advocacy; health service; women laborers

Abstrak. Pembangunan ketenagakerjaan sebagai bagian integral dari pembangunan nasional berdasarkan Pancasila dan Undang-undang dasar 1945, dilaksanakan dalam rangka pembangunan manusia seutuhnya dan pembangunan masyarakat Indonesia seluruhnya untuk meningkatkan harkat, martabat dan harga diri tenaga kerja serta mewujudkan masyarakat sejahtera, adil, makmur dan materiil maupun spriritual. Mengingat pentingnya peranan buruh dalam pembangunan khususnya dalam proses produksi, sudah sewajarnya dilakukan perlindungan, pemeliharaan dan pengembangan terhadap kesejahteraan buruh khususnya buruh perempuan, karena posisi buruh yang sangat lemah jika dibandingkan dengan posisi pengusaha. Posisi buruh yang lemah mengharuskan pengusaha untuk memberikan perlindungan jaminan sosial terhadap para pekerjanya. Jaminan sosial merupakan hak setiap warga negara bahkan termasuk warga negara asing yang menetap. Pelanggaran terhadap pelaksanaan jaminan sosial berarti pelanggaran terhadap hak asasi manusia (HAM). Hal ini sejalan dengan amanat UUD 45 yang telah diamandemen yaitu pasal 28 huruf d (1 dan 2) dan huruf h (3) juga pasal 34 (2); pasal-pasal tersebut menjelaskan bahwa negara melindungi setiap warganya dan berhak atas perlindungan dari segala macam bahaya, intimidasi dan perlakukan yang sama dalam menjalankan hidupnya. Dalam pelaksanaan dilapangan, tidak semua perusahaan melaksanakan jaminan sosial bagi para buruhnya, terutama buruh perempuan. Dimana banyak buruh perempuan yang masih dikategorikan lajang padahal mereka adalah tulang punggung keluarga, baik karena suami yang tidak bekerja maupun sebagai single parent. Sehingga dibutuhkan tindakan nyata dalam bentuk advokasi untuk merubah kebijakan perusahaan tersebut. Advokasi adalah cara ampuh untuk membawa perubahan positif dan memberdayakan orang dalam kehidupan mereka.

Kata Kunci: advokasi; pelayanan kesehatan; buruh perempuan

Permalink/DOI: 10.15408/harkat.v14i1.10397 


\section{Pendahuluan}

Kata “advokasi' (Mansour. 2001: iii) pada era rezim orde baru pernah menjadi kata yang menakutkan dan paling diwaspadai. Advokasi selalu diartikan sebagai usaha-usaha makar kalangan anti kemapanan untuk merongrong pemerintahan yang sah. Menurut Topatimasang, pemahaman bahwa advokasi merupakan pekerjaan para pengacara dan umumnya hanya berkaitan dengan praktek pembelaan oleh praktisi hukum di mahkamah peradilan, melahirkan pengertian advokasi yang amat sempit sebagai kegiatan beracara di peradilan (litigasi). Advokasi dianggap sebagai urusan dan monopoli yang berkaitan dengam ilmu dan praktik hukum. Hal ini bisa jadi dikarenakan dari asal kata advokasi dalam bahasa belanda yaitu advocaat, advocateur, yang berarti pengacara hukum, pembela atau peguam. Padahal jika kita mengadopsi kata "advokasi” dari bahasa inggris maka to advocate tidak hanya berarti "membela (to defend), tetapi bisa berarti 'memajukan' atau 'mengemukakan" (to promote) juga berarti betusaha "menciptakan" (to create) yang baru. Dengan kata lain juga berati melakukan perubahan (to change)

Menurut Epstein, \& Savage (1983) dalam Ezell (2001:22) advokasi The process of working with and/or on behalf of client (1) to obstain services or resources for clients that would not otherwise be provided (2) to modify extant policies, procedures, or practice that adversely impact clients, or (3) to promote new legislation or policies that will result in the provision of needed resources or services (adalah proses bekerja dengan dan/atau atas nama klien (1) untuk mendapatkan pelayanan atau sumber untuk klien yang tidak disediakan oleh pihak lain, (2) untuk memodifikasikan kebijakan, prosedur atau praktek-praktek pelaksanaan lebih luas yang dapat mempengaruhi klien, atau (3) untuk mempromosikan peraturan-peraturan dan kebijakan-kebijakan baru yang akan menghasilkan keuntungan terhadap sumbersumber pelayanan yang dibutuhkan).

Sedangkan menurut Ezell (2001:22) Advocacy consists of those purposives effort to change spesific existing or proposed plicies or practices on behalf of or with a specifik client or group of client," (advokasi terdiri dari usaha yang ditujukan untuk mengubah hal-hal spesifik atau mengusulkan kebijakan-kebijakan atau praktik-praktik yang diusulkan atas nama atau dengan klien atau kelompok klien tertentu).

Dalam pengertian diatas ada beberapa kata kunci dalam advokasi. Pertama to change, artinya hasil akhir dari advokasi adalah perubahan kebijakan atau praktek terhadap seuatu masalah yang menjadi sasaran. Kedua purposive, mengandung pengertian bahwa advokasi sebagai perencanaan dan perubahan hasil yang diusahakan terdiri dari studi, perencanaan, aksi dan evaluasi. Di lain pihak advokasi juga bersifat tersruktur dimana intervensi-intervensi yang dilakukan secara sistematik terhadap masalah dan kekuatankekuatan, rencana intervensi itu sendiri, rencana implementasi dari intervensi, evaluasi hasil dan bagaimana menentukan hasil yang diharapkan oleh klien. Ketiga adalah targets of change, yaitu mengidentifikasi dua target perubahan yakni kebijakan dan praktik (plocies and practices). Catatan pentingnya bahwa target dari intervensi bukan hanya klien itu sendiri tetapi juga menyangkut agen perubahan tersebut beroperasi. Keempat adalah with and on behalf of, ungkapan ini mengandung arti bahwa definisi advokasi tidak menunjukkan indikasi tertentu, tidak mempunyai batas waktu, tetapi pada hasil perubahan yang dilahirkan atas nama klien. menurut Scneider dan Lester (2001:56-61) terdapat banyak kekurangan, menurutnya minimal ada 6 kriteria dalam menjalankan advokasi pekerjaan sosial, yaitu adanya kejelasan (clarity), terukur (measurable) memfokuskan diri pada aktifitas, bukan peran atau hasil dari 
advokasi (focus on activity, not roles or outcomes of advocacy) dan lengkap (comprehenship). Sehingga Scneider membuat definisi baru tentang advokasi pekerjaan sosial sebagai berikut Social work advocacy is the exclusive and mutual representation of a client(s) or a cause in a forum, attempting to systematically influence decision making in an unjust or unresponsive system(s). (advokasi pekerjaan sosial sebagai perwakilan eksklusif dan timbal balik untuk seorang atau beberapa klien atau untuk sebuah perkara dalam sebuah forum, upaya sistematik untuk mempengaruhi pengambilan keputusan dalam sistem yang tidak adil atau tidak responsif).

Sementara jika dilihat dari definisi diatas, ada banyak jenis advokasi dalam pekerjaan sosial, dalam kajian kali ini yang akan digunakan adalah advokasi kelas, yaitu Advokasi kelas/kelompok (class advocacy). Pekerja sosial harus sering memberikan pelayanan advokasi bagi kelompok-kelompok klien atau untuk segmen penduduk yang memiliki masalah yang sama. Secara khusus, advokasi kelompok terdiri dari tindakan-tindakan yang ditujukan untuk mengatasi hambatan-hambatan yang membatasi sekelompok atau kategori orang-orang tertentu dalam merealisasikan hak-hak sipil atau dalam penerimaan manfaat yang ditujukan bagi mereka. Hal ini biasanya memerlukan upaya yang bertujuan untuk mengubah peraturanperaturan lembaga, kebijakan sosial atau hukum dan perundang-undangan. Akibatnya, advokasi kelompok memerlukan kegiatan dalam arena politik dan legislasi serta dalam membangun koalisi dengan organisasi-organisasi yang berkepentingan dengan isu yang sama. Alasan mengapa menggunakan advokasi kelas karena dalam perusahaan ini terdapat masalah yang cukup penting dan dialami hampir semua buruh, terutama buruh perempuan dimana walaupun sudah menikah dan menjadi tulang punggung keluarga, tetapi tetap saja diperhitungkan sebagai lajang yang tidak mempunyai tanggungan, baik gaji, tetapi dalam hal jaminan sosial juga. Penelitian ini lebih fokus untuk pada jaminan sosial buruh perempuan.

Advokasi merupakan proses yang dinamis yang menyangkut seperangkat pelaku, gagasan, agenda dan politik yang selalu berubah. Menurut Sharma (2004:18-20) proses advokasi dibagi menjadi lima tahap, yaitu:

a) Tahap pertama adalah mengidentifikasi masalah untuk mengambil tindakan kebijakan. Tahap ini juga mengacu pada penetapan agenda. Terdapat problem tidak terbatas jumlahnya dan yang perlu diperhatikan, tetapi tidak semua masalah masuk ke dalam agenda. tetapi tidak semuanya harus mendapatkan tempat di dalam agenda tindakan. Pekerja social menentukan problem mana yang harus dituju dan diusahakan untuk mencapai lembaga yang menjadi sasaran agar diketahui bahwa problem tersebut memerlukan tindakan.

b) Tahap kedua, yaitu merumuskan solusi. Pekerja sosial dan pelaku kunci yang lain mengusulkan solusi mengenai problem tersebut dan memilih salah satu yang layak ditangani secara politis, ekonomis dan sosial

c) Tahap ketiga, membangun kemauan politik (political will) untuk bertindak menangani problem itu dan mendapatkan solusinya merupakan bagian terpenting dari advokasi. Tindakan didalam tahap ini meliputi koalisi, menemui para pengambil keputusan, membangun kesadaran dan menyampaikan pesan yang efektif.

d) Tahap keempat, melaksanakan kebijakan. Jika problem telah diketahui, solusinya diterima dan ada kemauan politik untuk bertindak, dan semuanya harus berjalan secara serentak. Keaadaan inilah yang tepat 
bagi pekerja sosial untuk bertindak melaksanakan kebijakan.

e) Tahap kelima adalah evaluasi. Advokasi yang baik harus menilai efektifitas usahanya yang telah berjalan dan menentukan sasaran berdasarkan pada pengalaman mereka. Para penyumbang pikiran dan institusi yang menerima perubahan kebijakan secara poriodik perlu mengevaluasi efektivitas perubahan tersebut.

Tahapan tersebut sebaiknya dianggap lentur dan tidak kaku, karena tahapan tersebut mungkin saja terjadi bersamaan atau berurutan, kecuali prosesnya sendiri yang mungkin terhenti atau berbalik.

Jaminan sosial merupakan perlindungan dasar yang diperlukan oleh setiap manuasi termasuk di dalamnya tenaga kerja. Perlindungan dasar dimaksud untuk mencegah dan mengatasi keterbelakangan, ketergantungan, keterlantaran serta kemiskinan pada umumnya.

Dalam konvensi ILO tahun 1952 no. 102 mengenai jaminan sosial (standar minimum) dinayatakan bahwa jaminan sosial adalah perlindungan yang diberikan masyarakat untuk para anggotanya melalui seperangkat instrumen publik, terhadap kesulitan ekonomis dan sosial yang disebabkan karena terhentinya atau turunnya penghasilan yang diakibatkan karena sakit, hamil, kecelakaan kerja, pengangguran, cacat, hari tua, dan kematian; pemberian perawatan medis; dan pemberian subsidi bagi keluarga yang mempunyai anak.

Dalam Undang-Undang nomor 11 tahun 2009 tentang kesejahteraan sosial dalam pasal 1 disebutkan bahwa Penyelenggaraan kesejahteraan sosial adalah upaya yang terarah, terpadu, dan berkelanjutan yangdilakukan Pemerintah, pemerintah daerah, dan masyarakat dalam bentuk pelayanan sosial gunamemenuhi kebutuhan dasar setiap warga negara, yang meliputi rehabilitasi sosial, jaminan sosial, pemberdayaan sosial, dan perlindungan sosial.

Sejalan dengan pengertian diatas, pada tahun 2004 pemerintah mengeluarkan Undangundang nomer 40 tahun 2004 tentang Sistem jaminan Sosial Nasional (SJSN) dimana disebutkan bahwa Jaminan sosial adalah salah satu bentuk perlindungan sosial untuk menjamin seluruh rakyat agar dapat memenuhi kebutuhan dasar hidupnya yang layak. Untuk dapat melaksnakan jaminan sosial tersebut bagi seluruh rakyatnya pada tahun 2011 pemerintah mengeluarkan undang-undang nomor 24 tahun 2011 tentang Badan Penyelenggara Jaminan Sosial (BPJS), dalam undang-undang tersebut diatur 2 jaminan sosial yaitu jaminan ketenagakerjaan (BPJS Ketenagakerjaan) dan jaminan kesehatan (BPJS Kesehatan).

Menurut hasil penelitian Universitas Indonesia tahun 2000 beberapa alasan mengapa masyarakat membutuhkan jaminan sosial yaitu:

a) Perubahan struktur ekonomi dan jumlah penduduk perkotaan

Perluasan kesempatan kerja dan peluang berusaha disektor-sektor industri, konstruksi, perdagangan, transportasi, perbangkan, asuransi dan jasa telah menarik penduduk bermigrasi ke kota. Sumber penghasilan perkotaan memang lebih menjanjikan jumlahnya dibandingkan dengan sumber penghasilan pedesaan yang lebih banyak bergantung kepada pertanian

b) Langkah kesempatan kerja dan berusaha

Langkah kesempatan kerja dan berusaha menyebabkan tingkah upah dan penghasilan tenaga kerja formal maupun informal rendah atau kurang memiliki daya tawar. Kebijakan upah minimum regional yang semula dimaksudkan sebagai jaringan pengaman agar upah tidak jatuh secara drastis, cenderung menjadi alat pembenaran untuk menentukan tingkat upah yang rendah 


\section{c) Perubahan struktur usia}

Usia harapan hidup penduduk Indonesia telah meningkat dari usia 48 tahun diawal tahun 1960-an menjadi 63 tahun pada saat ini. Sementara jumlah penduduk diatas 60 tahun kini telah mencapai angka 15 juta jiwa (sama dengan penduduk Belanda), namun usia pensiun secara formal masih ditetapkan pada usia berjuang sendiri untuk memenuhi kebutuhan hidupnya dimasa yang relatif terlalu muda untuk saat ini.

\section{d) Pergeseran Kesempatan Kerja}

Pergeseran struktur ekonomi dari pertanian ke Industri telah menciptakan lapangan kerja yang selektif dan penuh persaingan. Akibatnya jumlah tenaga kerja di sektor industri meningkatkan tajam, bahkan karena proses seleksi dan kompetisi yang ketat tidak jarang terjadi PHK secara sepihak atau pengusaha tidak mampu bersaing di pasar global sehingga perusahaan terpaksa tutup.

Kesejahteraan sosial dalam arti yang sangat luas mencakup berbagai tindakan yang dilakukan manusia untuk mencapai tingkat kehidupan masyarakat yang lebih baik. Menurut Friedlander dalam Adi (2002: 184) Kesejahteraan sosial adalah sistem pelayanan dan institusi sosial yang terorganisir, yang dirancang untuk membantu individu dan kelompok untuk mencapai standart kehidupan dan kesehatan yang menonjol.

Menurut Undang-undang Nomor 11 tahun 2009 bahwa kesejahteraan sosial adalah kondisi dimana terpenuhinya kebutuhan material, spiritual dan sosial warga negara agar dapat hidup layak dan mampu mengembangkan diri, sehingga mampu melaksanakan fungsi sosialnya.

Dari pengetian diatas, kesejahteraan sosial dapat dianalogikan seperti kesehatan jiwa, sehingga dapat dilihat dari berbagai sudut pandang sebagaimana dijelaskan oleh Adi (2003:41-47), yaitu:

a) Kesejahteraan Sosial sebagai suatu Keadaan (Kondisi)

Hal ini terlihat dalam UU kesejahteraan sosial dimana menyebutkan bahwa Kesejahteraan sosial adalah kondisi dimana terpenuhinya kebutuhan material, spiritual dan sosial warga negara agar dapat hidup layak dan mampu mengembangkan diri, sehingga mampu melaksanakan fungsi sosialnya.

b) Kesejahteraan Sosial sebagai Kegiatan

Pandangan ini datang dari Friedlander yang menggambarkan kesejahteraan social sebagai sustu system pelayanan (kegiatan) yang dirancang guna meningkatkan taraf hidup masyarakat

c) Kesejahteraan Sosial sebagai Gerakan

Sebagai suatu gerakan, isu kesejahteraan social sudah menyebar luas hamper ke seluruh dunia. Gerakan ini menjadi suatu gerakan tersendiri yang bertujuan menginformasikan kepada seluruh dunia bahwa masalah kesejahteraan social harus mendapat perhatian masyarakat dunia, baik secara global maupun parsial. Kemunculan berbagai gerakan dalam wujud organisasi local, regional, maupun internasional yang berusaha menangani kasus kesejahteraan social ini.

\section{Metode}

Penelitian ini menggunakan penelitian deskriptif yang bertujuan agar dapat menggambarkan berbagai fenomena realitas sebenarnya yang menjadi obyek penelitian agar lebih mendalam dan memperoleh data yang diinginkan dengan melihat dan mempelajari advokasi pelayanan kesehatan bagi buruh perempuan. 


\section{Hasil dan Pembahasan}

PT Sederhana bergerak dalam bidang pemintalan benang. Hasil pemintalan benang ini merupakan barang produkdi setengah jadi, artinya benang yang dihasilkan belum bias diproses menajadi kain pembuat baju, masih membutuhkan beberapa proses lagi. Bahan baku benang 90 \& diimpor dari negara Amerika serikat, Pakistan, Uzbekistan dan China, dan hanya $10 \%$ yang merupakan produk local Indonesia tepatnya dari Makassar. Sedangkan pemasaran dari hasil produksi adalah untuk keperluan dalam negeri sebesar 60\%, dan $40 \%$ diekspor ke Malaysia, Amerika Serikat, Hongkong dan Jepang.

PT Sederhana mempunyai tenaga kerja sebanyak 980 orang, 784 orang (80\%) adalah pekerja perempuan. Kebanyakan tenaga kerja berasal dari masyarakat pribumi dimana perusahaan beroperasi. Ini merupakan komitmen perusahaan untuk membangun daerah dan mengurangi angka pengangguran. Tidak heran $80 \%$ tenaga kerja berasal dari Bekasi, dan 20\% merupakan pendatang dari Lampung, Jawa Tengah dan Jawa Timur.

PT Sederhana melaksanakan jaminan kepada semua pekerjanya. Jaminan yang sudah terdaftar adalah BPJS Ketenagakerjaan, karena BPJS ini bersifat wajib bagi pekerja. Sementara BPJS kesehatan tidak diikut sertakan dalam program pemerintah, pihak perusahaan hanya menyediakan klinik kesehatan. Dimana dalam klinik ini hanya terdapat 1 tenaga kesehatan (perawat) yang stanbye setiap hari kerja (senin sabtu), dan dokter yang datang 2 kali dalam seminggu.Jenis pelayanan yang diberikan adalah pertolongan pertama, pemeriksaaankehamilan termasuk di dalamnya pelayanan keluarga berencana $(\mathrm{KB})$.

Karena diselenggarakan sendiri, kondisi pelayanan kesehatan yang diberikan kepasa buruh kurang maksimal. Pertama pelayanan kesehatan di perusahaan ini belum dilaksanakan secara menyeluruh sesuai dengan pasal $16 \mathrm{UU}$ no. 3 tahun 1992 tentang ketenagakerjaan. Dalam UU tersebut disebutkan bahwa Istri/Suami dan maksimal 3 orang anak menjadi tanggungan perusahaan dalam hal kesehatan. Kedua perusahaan tidak menanggung biaya melahirkan bagi pekerja perempuan, dengan alasan bahwa melahirkan bukan masuk dalam kategori sakit, tetapi merupakan kodrat setiap perempuan. Ketiga, berkaitan dengan kesehatan perempuan, perusahaan belum melaksanakan cuti sakit bulanan bagi perempuan (dua hari pertama menstruasi setiap bulannya). Keempat, ada indikasi bahwa para pekerja menyalahgunakan alasan sakit, dan meminta rujukan ke Klinik/RS rujukan, sementara yang sakit adalah anggota keluarganya.

\section{Simpulan}

Proses advokasi dilakukan oleh buruh dan serikat pekerja PT sederhana dibantu oleh pekerja sosial melakukan tahapan advokasi seperti yang disampaikan oleh Sharma (2004: 18-20) sebagai berikut:

\section{Tahap Pertama: Identifikasi Masalah}

Hasil identifikasi masalah terhadap kondisi buruh PT Sederhana dihasilkan masalahmasalah sebagai berikut:

a) Terdapat diskriminasi dalam pembagian kerja antara perempuan dan laki-laki, dimana para buruh laki-laki lebih beruntung yaitu dapat menduduki posisi supervisor sedangkan buruh perempuan selamanya aka nada di arena produksi, kemudian posisi buruh perempuan selalu dikategorikan single, walaupun sudah menikah dan ada beberapa buruh perempuan yang menjadi tulang punggung keluarga. Hal ini jelas bertentangan dengan konvensi ILO No. 100 tahun 1951 tentang pengupahan yang sama bagi pekerja laki-laki dan perempuan dan konvensi No. 111 tahun 1958 tentang 
diskriminasi dalam pekerjaan dan jabatan, serta UU No. 7 tahun 1984 tentang pengesahan konvensi mengenai penghapusan segala bentuk diskriminasi terhadap perempuan.

b) Kesempatan bersosialisasi antar sesama buruh yang sangat kecil karena tidak ada waktu istirahat yang pasti. Hal ini menyebabkan buruh harus mensiasati waktu yang ada untuk istirahat, makan dan beribadah, biasanya dilakukan secara bergantian. Hal ini merupakan pelanggaran terhadap ketentuan UU No. 13 tahun 2013, pasal 79 ayat 1 yang menyebutkan bahwa pengusaha harus menyediakan waktu istirahat sekurang-kurangnya setengah jam setelah buruh bekerja selama empat terus menerus, dan waktu istirahat tersebut juga harus masuk kedalam jam kerja Pasal 80 juga menjamin kebebasan bagi buruh untuk melaksanakan ibadah sesuai dengan agama dan keyakinanya.

c) Soal pemakaian masker yang berkaitan dengan kesehatan. Pemakaian masker memang diwajibkan, tetapi tidak semua buruh menggunakan masker pada saat bekerja. Hal ini dikarenakan tidak ada sanksi tegas terhadap pelanggaran tersebut. Padahal dalam UU no. 3 tahun 1999 disebutkan bahwa sifat dari jaminan kesehatan adalah pencegahan.

d) Dalam pelayanan kesehatan perusahaan belum melaksanakan sesuai dengan ketentuan yang berlaku, yaitu rawat jalan tingkat pertama, rawat jalan tingkat lanjutan, rawat inap, pemeriksaaan kehamilan dan ppertolongan persalinan, penunjang diagnosis, pelayanan khusus dan gawat darurat. Hal ini tidak sesuai dengan UU no. 39 tahun 2009 tentang kesehatan pasal 30 tentang fasilitas pelayanan kesehatan.

\section{Tahap kedua: Merumuskan Masalah}

Perlu perdebatan yang cukup alot dalam menentukan masalah mana yang paling prioritas. Proses advokasi ini dilakukan oleh buruh, serikat pekerja dengan didampingi oleh pekerja sosial. Merasa semua maslah itu penting, tetapi dlam merumuskan masalah mana yang prioritas, buruh dan serikat pekerja membuat skala prioritas, kebaikan dan keburukan dan dampak apa yang akan ditimbulkan jika memilih masalah ini. Setelah melalui proses yang panjang akhirnya sepakat bahwa yang menjadi masalah utama adalah pelayanan kesehatan, dengan alasan yang disepakati bersama bahwa pelayanan kesehatan adalah maslah utama yang harus diselesaikan, karena ini menyangkut dan berlaku bagi semua buruh tanpa kecuali.

\section{Tahap Ketiga: Membangun kemauan politik untuk menangani masalah}

Bagian ini adalah bagian terpenting dalam proses advokasi, artinya banyak pihak yang harus terlibat dan dilibatkan dalam proses ketiga ini. Serikat pekerja sebagai motor pelaksanaan advokasi ini harus bekerja dan menjalin banyak kalangan. Hal pertama yang dilakukan adalah menyamakan persepsi ke semua pengurus serikat pekerja bahwa ini adalah penting dan masalah bersama. Penyamaan persepsi dilakukan dengan mengedukasi para pengurus dengan berdiskusi tentang UU dan kebijakan perintah tentang hak dan kewajiban pekerja. Selain berdiskusi mereka juga mengkritisi dengan cara mencatat atas ketidaksesuain antara kebijakan perusahaan dengan kebijakan pemerintah. Kedua adalah ketika dalam tubuh serikat pekrja sudah satu persepsi dengan pengetahuan yang sama, maka untuk memudahkan serikat pekerja didampingi pekerja sosial membuat angket dan disebarkan ke semua buruh. Hasil angket inilah teridentifikasi keinginan dan kebutuhan buruh, yang sudah dikumpulkan dan tersaji dalam tahap pertama.Selain survey dengan angket tersebut, 
serikat pekerja juga bergerak mengedukasi para buruh tentang hak dan kewajibannya sehingga para buruh (perwakilan) mengetahui hak dan kewajiban.Dukungan para buruh yang selama ini diam merupakan energy positif yang diterima oleh serikat pekreja untuk menuntaskan advokasi ini.Ketiga adalah menggalang dukungan dari berbagai pihak baik internal maupun eksternal.Dalam hal ini buruh adalah kekuatan yang utama. Galangan dukungan yang lain adalah dari cabang serikat pekerja, dinas tenaga kerja dan juga perusahaan. Dalam hal ini perusahaan diwakili oleh direktur operasional yang membawahi operasional pabrik dan SDM, dan tenaga kesehatan (perawat). Mendapatkan dukungan dari perusahaan tidaklah mudah, perlu kerja keras dan argumentasi yang kuat, sehingga pihak perusahaan mau memenuhi tuntutan seikat pekerja dan buruh. Proses dukungan ini tidak selamanya mulus dan lancar, misalnya dari pihak buruh juga tidak sedikit yang menghindar karena ketakutan, takut PHK. Karena pihak buruh merasa selama ini yang diterima sudah lebih dari cukup, hal ini dikaitkan dengan susahnya mencari pekerjaan saat ini, dengan persaingan yang ada. Apalagi dengan latar belakang pendidikan yang banyak diantara meraka hanya berpendidikan SD. Ketakutan akan PHK adalah alasan mereka tidak mau ikut campur dan menerima apa saja yang diberikan oleh perusahaan. Selain buruh, pihak perusahaan juga menjadi hambatan dalam pelaksanaan advokasi ini. Dimana perusahaan merasa apa yang dilakukan oleh serikat pekerja adalah rekayasa dan bukan keinginan apalagi kebutuhan buruh secara keseluruhan. Perusahaan tidak percaya begitu saja dengan gerakan serikat pekerja, dengan cara melakukan pengecekan kepada para buruh apakah benar perubahan pelayanan kesehatan adalah keinginan dan kebutuhan para buruh. Di sisi lain perusahaan juga merasa berat dengan beban baru jika pelayanan kesehatan yang selama ini dengan system klinik harus beralih ke BPJS kesehatan.
Seperti biasa perusahaan dimanapun akan menginingkan keuntungan yang berlipat dengan modal yang minimalis. Dalam hal ini kalkulasinya adalah jika BPJS Kesehatan maka perusahaan tiap bulannya harus mengeluarkan dana yang cukup besar untuk membayar preminya, walaupun para buruh tidak menggunakan fasilitas BPJS kesehatan tersebut karena tidak sakit, berbeda dengan sistem klinik yang akan mengeluarkan dana ketika buruh perlu rujukan saja, plus tidak akan menganggung pihak keluarga buruh.

\section{Tahap Keempat: Melaksanakan Kebijakan}

Setelah melakukan perundingan yang panjang antar serikat pekerja dengan serikat pekerja, serikat pekerja dengan buruh, serikat pekerja dengan perusahaan dengan modal dukungan dari dinas ketenaga kerjaan, akhirnya pihak keluarga bersedia melakukan peralihan pelayanan kesehatan dengan polan BPJS kesehatan. Tetapi pelaksanaan pola BPJS ini tidak bias langsung dilaksanakan mengingat kesepakatan ini dilakukan di bulan oktober, dimana anggaran tahun berjalan sudah disusun, sehingga perusahaan meminta waktu sampai akhir tahun dan di taun mendatang pelayanan kesehatan bagi seluruh buruh sudah dengan pola BPJS.

\section{Tahap Kelima: Evaluasi}

Dengan keterbatasan peneliti, tahap evaluasi pelaksanaan hasil advokasi tidak bias dilaksanakan, karena pelaksanaan advokasi baru akan dilaknsakan pada tahun mendatang. Tetapi yakin dengan komitmen bersama yang sudah ditanda tangani dari berbagai unsur yaitu pihak buruh, serikat pekerja, perusahaan dengan diketahui oleh dinas kesehatan, peneliti yakin bahwa kebijakan ini akan dilaksanakan. Harapannya dengan pelaksanaan kesehatan dengan pola BPJS kesehatan dan produktivitas buruh makin meningkat, dan perusahaan tetap beroperasi. 


\section{Daftar Pustaka}

Adi, Isbandi Rukminto. 2002. Pemikiranpemikiran dalam Pembangunan Kesejahteraan Sosial. Jakarta: Lembaga Penerbit Fakultas Ekonomi Universitas Indonesis

Adi, Isbandi Rukminto. 2003. Pemberdayaan, Pengembangan Masyarakat dan Intervensi Komunitas (Pengantar pada Pemikiran dan Pendekatan Praktis) Edisi Revisi. Lembaga Penerbit Fakultas Ekonomi Universitas Indonesis

Depnakertrans \& UI. 2000. Studi Jenis-jenis Jabatan yang Potensial menimbulkan deskriminiasi bagi Pekerja Wanita di Sektor Industri Pengolahan.Depok: Badan Perencanaan dan Pengembangan Tenaga Kerja Depnakertrans dan Pusat Penelitian Kemasyarakatan dan Budaya UI.
Ezell, Mark. 2001. Advocacy in Human Services. Canada: Thomson Learning

Fakih, Mansour. 2001. Kata Pengantar dalam Topatimasang, Roem., Fakih, Mansour., \$ Raharjo, Toto. (ed). Dalam Merubah Kebijakan Publik: Panduan Pelatihan Advokasi untuk Organisasi non Pemerintah. Yogyakarta: Pustaka Pelajar

Friedlander, Walter A., \& Robert Z. Apte. 1980. Introduction to Social Welfare, fifth edition. New Jersey: Englewood Cliffs, Prentice Hall 